\title{
Domain Regulation of Imprinting Cluster in Kip2/Litl Subdomain on Mouse Chromosome 7F4/F5: Large-Scale DNA Methylation Analysis Reveals That DMR-Litl Is a Putative Imprinting Control Region
}

\author{
Hitomi Yatsuki, ${ }^{1}$ Keiichiro Joh, ${ }^{1}$ Ken Higashimoto, ${ }^{1}$ Hidenobu Soejima, ${ }^{1}$ Yuji Arai, ${ }^{2}$ \\ Youdong Wang, ${ }^{1}$ Izuho Hatada, ${ }^{3}$ Yayoi Obata, ${ }^{3}$ Hiroko Morisaki, ${ }^{2}$ \\ Zhongming Zhang, ${ }^{1}$ Tetsuji Nakagawachi, ${ }^{1}$ Yuji Satoh, ${ }^{1}$ and Tsunehiro Mukai ${ }^{1,4}$ \\ ${ }^{1}$ Department of Biochemistry, Saga Medical School, Saga, Saga 849-8501, Japan; ${ }^{2}$ Department of Bioscience, National \\ Cardiovascular Center Research Institute, Fujishiro-dai, Suita, Osaka 565-8565, Japan; ${ }^{3}$ Gene Research Center, Gunma \\ University, Showa-machi, Maebashi 371-8511, Japan
}

\begin{abstract}
Mouse chromosome 7F4/F5, where the imprinting domain is located, is syntenic to human 11p15.5, the locus for Beckwith-Wiedemann syndrome. The domain is thought to consist of the two subdomains Kip2 (p57 ${ }^{\text {kip2}) / L i t l ~}$ and Igf2/H19. Because DNA methylation is believed to be a key factor in genomic imprinting, we performed large-scale DNA methylation analysis to identify the cis-element crucial for the regulation of the Kip2/Litl subdomain. Ten CpG islands (CGIs) were found, and these were located at the promoter sites, upstream of genes, and within intergenic regions. Bisulphite sequencing revealed that CGIs 4, 5, 8, and 10 were differentially methylated regions (DMRs). CGls 4, 5, and 10 were methylated paternally in somatic tissues but not in germ cells. CGI8 was methylated in oocyte and maternally in somatic tissues during development. Parental-specific DNase I hypersensitive sites (HSSs) were found near CGI8. These data indicate that CGI8, called DMR-Litl, is not only the region for gametic methylation but might also be the imprinting control region (ICR) of the subdomain.
\end{abstract}

DNA methylation is an epigenetic phenomenon in which cytosine is modified to 5-methyl cytosine. In the mammalian genome, DNA methylation has been shown to be associated with important phenomena such as tissue-specific gene expression, X-chromosome inactivation, carcinogenesis, and genomic imprinting (Razin and Cedar 1991; Avner and Heard 2001; Baylin et al. 2001; Reik and Walter 2001). Genomic imprinting is a specific example of the epigenetic phenomenon whereby gene expression is restricted to only one parental allele. Most imprinted genes exist in clusters, suggesting a coordinated regulation of imprinted genes (FergusonSmith and Surani 2001; Reik and Walter 2001). Establishment of the imprint must occur in gametogenesis because this is the only chance during development in which the male and female genomes are in distinct compartments (Tilghman 1999; Reik and Walter 2001). In fact, several imprinted genes have been reported in which methylation was inherited from gametes (Stöger et al. 1993; Tremblay et al. 1995; Shemer et al. 1997). This is called gametic methylation and is thought to be a gametic imprint.

One of the two major imprinting domains is mapped to

${ }^{4}$ Corresponding author.

E-MAIL mukait@post.saga-med.ac.jp; FAX 81-952-34-2067.

Article and publication are at http://www.genome.org/cgi/doi/10.1101/ gr.110702. human chromosome $11 \mathrm{p} 15.5$, a locus for BeckwithWiedemann syndrome (BWS). Its murine ortholog is on chromosome 7F4/F5 (Caspary et al. 1998; Paulsen et al. 1998). The gene organization of the region is highly conserved between human and mouse (Engemann et al. 2000; Onyango et al. 2000; Paulsen et al. 2000; Yatsuki et al. 2000). Transgenic mice, gene targeting, and translocation experiments have suggested that this domain may be separated into two subdomains (Sun et al. 1997; Zhang et al. 1997; Caspary et al. 1998; Cleary et al. 2001). One of these subdomains includes the $I g f 2$ and $H 19$ genes (Igf2/H19 subdomain). The expression of Igf2 and $H 19$ is epigenetically controlled by an imprinting control region (ICR), which is located near a CpG island (CGI) upstream of $\mathrm{H} 19$ and is characterized by the differentially methylated region (DMR; Thorvaldsen et al. 1998). This subdomain, however, does not affect the imprinting of Kvlqt1 and $p 57^{\text {Kip2 }}$, and vice versa (Sun et al. 1997; Caspary et al. 1998). These genes are several hundred kilobases away from the Igf2/ H19 subdomain and possibly consist of another subdomain (the Kip2/Lit1 subdomain). Therefore, another ICR will be identified in this region (Fig. 1). The discovery of human LIT1(KCNQ1-AS, KCNQ1OT1), and the finding that loss of imprinting of this gene is independent of $I G F 2$ imprinting, further support the above notion (Lee et al. 1999; Mitsuya et al. 1999; Smilinich et al. 1999; Feinberg 2000; Maher and Reik 2000). In fact, it was proposed that the CGI of Lit1 is a 
mouse 7F4/F5

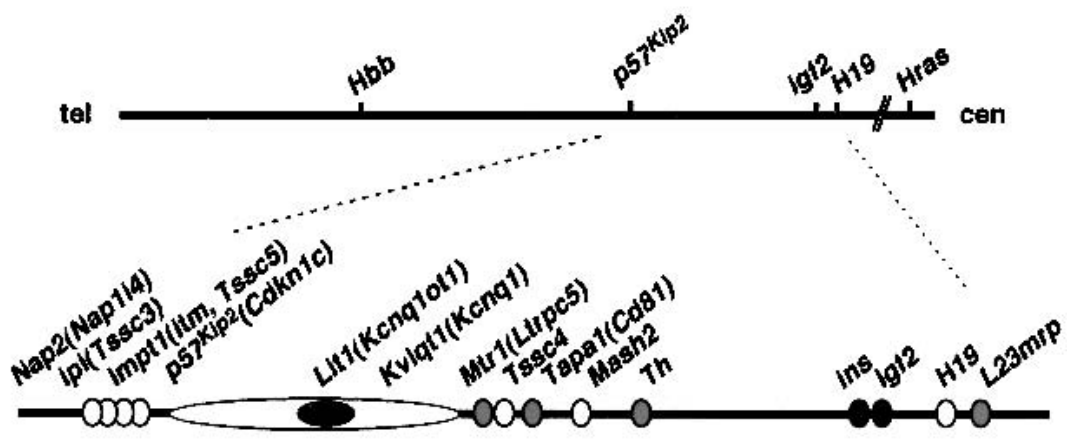

$100 \mathrm{~kb}$
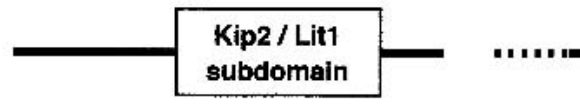

Igf2 / H19

subdomain

Figure 1 Imprinting domain and a schematic physical map of mouse 7F4/F5. The relative position of the genes is based on previously published data. The imprinting status is shown by filled circles (paternally expressed), open circles (maternally expressed), and gray circles (biallelic expression). The locations of the Kip2/Lit1 and Igf2/H19 subdomains are shown below the map.

consequently both alleles were expressed (Fig. 1, top of Fig. 2; Paulsen et al. 1998; Yatsuki et al. 2000).

Here we analyzed the methylation status of the mouse genomic region corresponding to the Kip2/ Lit1 subdomain through germ cell, early embryo, and adult somatic tissue to find the DMRs and the regions for gametic methylation. We therefore performed sodium bisulphite-genomic sequencing of a total of 10 CGIs in this domain. From our results, CGI4 ( $p 57^{\text {Kip } 2}$ upstream), CGI5 ( $p 57^{\text {Kip2 }}$ promoter), CGI8 (Lit1 promoter), and CGI10 (Tssc4 promoter) were shown to be the DMR in somatic tissues. Furthermore, CGI8 and not CGIs 4, 5, or 10 was solely methylated in germ cells, suggesting that the CGI8 would be the ICR in this subdomain.

\section{RESULTS}

\section{Identification of CGIs in Mouse Kip2/Litl Subdomain}

candidate for the ICR and may regulate $p 57^{\text {Kip } 2}$ expression (Engemann et al. 2000; Horike et al. 2000).

Accurate mapping and analysis of genomic DNA methylation at developmental stages are essential for understanding the regulation of the Kip2/Lit1 subdomain, because DNA methylation is important for the establishment and/or maintenance of imprinting. Although a candidate region has been identified, the underlying mechanism remains to be clarified. We sequenced approximately $500 \mathrm{~kb}$ of the region between Nap2(Nap1l4) and Tapa1 (Cd81) in mouse where eight genes were clustered (Fig. 1; Yatsuki et al. 2000). In this subdomain, Nap2 (Nap1l4), Ipl (Tssc3), Impt1 (Itm, Tssc5), p57 ${ }^{\mathrm{Kip} 2}$ (Cdknlc), Kvlqt1(Kcnq1), and Tssc4 were imprinted and expressed from maternal allele (Hatada and Mukai 1995; Qian et al. 1997; Dao et al. 1998; Gould and Pfeifer 1998; Morisaki et al. 1998; Engemann et al. 2000). Lit1(Kcnqt1-AS, Kcnq1ot1) was also imprinted but was expressed from paternal allele (Smilinich et al. 1999; Yatsuki et al. 2000). Mtr1(Ltrpc5) was not imprinted, and
We reported previously the nucleotide sequence of $390 \mathrm{~kb}$ between Kvlqt1 and Tapa1 (Yatsuki et al. 2000) and extended the sequencing up to $500 \mathrm{~kb}$ between Nap2 and TapaI (accession nos. AP001293 and AP001294), which covered an entire Kip2/Lit1 subdomain. It has been reported that many imprinted genes have been differentially methylated in their control regions (Thorvaldsen et al. 1998). The DMR usually exists in CGI. We have identified 10 CGIs based on sequence information around this region (Fig. 2). These CGIs were named CGIs 1 to 10 (Table 1 ). CGIs $1,3,5,8,9$, and 10 were located in the promoter region of the genes (Table 1, Fig. 2). CGIs 2 and 4 were upstream of genes, and CGIs 6 and 7 existed in an intergenic region. To determine the methylation status of the parental alleles, we searched for nucleotidesequence polymorphisms between two mouse strains, C57BL/6 and PWK, that would allow us to distinguish between two parental alleles in their $F_{1}$ hybrid mice. Several polymorphisms were found and are shown in Table 1.

Table 1. The Position of CGIs Based on Sequences and DNA Polymorphisms in Amplified Regions

\begin{tabular}{|c|c|c|c|c|c|c|}
\hline CGI & Databases & Position of CGI & $\begin{array}{l}\text { Polymorphism } \\
\text { (B6/PWK) }\end{array}$ & $\begin{array}{c}\text { PCR- } \\
\text { amplified region }\end{array}$ & $\begin{array}{l}\text { Position of first } \\
\text { presented } \mathrm{CpC}\end{array}$ & $\begin{array}{l}\text { Transcriptional start } \\
\text { site near the CGI }\end{array}$ \\
\hline 1 & AP001294 & $30585-31349(765 \mathrm{bp})$ & $30704 \mathrm{~A} / \mathrm{T}$ & $30480-30877(25)$ & 30514 & Nap2 $30826\left(5^{\prime}-3^{\prime}\right)$ \\
\hline 2 & AP001294 & $76525-76745(221 \mathrm{bp})$ & $76541 \mathrm{~T} / \mathrm{G}$ & $76469-76795(20)$ & 76489 & \\
\hline 3 & AP001294 & $77348-78008(661 \mathrm{bp})$ & $77447 \mathrm{C} / \mathrm{T}$ & $77320-77980(47)$ & 77342 & Ipl $77376\left(5^{\prime}-3^{\prime}\right)$ \\
\hline 4 & AP001293 & $30370-30593(224 \mathrm{bp})$ & $30214 \mathrm{G} / \mathrm{A}$ & $30134-30465(26)$ & 30191 & \\
\hline 5 & AP001293 & $33971-36417(2447 b p)$ & $34012 \mathrm{~T} / \mathrm{G}$ & $33926-34377(53)$ & 33986 & $p 57^{K i p 2} 34481\left(5^{\prime}-3^{\prime}\right)$ \\
\hline 6 & AP001293 & $49478-50205(728 \mathrm{bp})$ & $49380 \mathrm{G} / \mathrm{A}$ & $49346-49694(29)$ & 49373 & \\
\hline 7 & AP001293 & $57282-57713(432 \mathrm{bp})$ & $57421 \mathrm{G} /-$ & $57188-57705$ (49) & 57322 & \\
\hline \multirow[t]{2}{*}{8} & AP001295 & 8a $101981-102270$ (290 bp) & $101803 \mathrm{~A} / \mathrm{G}$ & 101735-102282(23) & 101956 & Lit1 $101974\left(5^{\prime}-3^{\prime}\right)$ \\
\hline & & 8b $102713-103490(778 \mathrm{bp})$ & $103181 \mathrm{G} / \mathrm{C}$ & $102639-103483(22)$ & 103099 & \\
\hline 9 & AP001287 & $32410-33175(766 \mathrm{bp})$ & $32315 \mathrm{G} / \mathrm{A}$ & $32256-32707(34)$ & 32318 & Kvlqt1 $32717\left(3^{\prime}-5^{\prime}\right)$ \\
\hline 10 & AP001287 & $70536-71088(553 \mathrm{bp})$ & $70844 \mathrm{G} / \mathrm{A}$ & $70628-71113(39)$ & 70648 & Tssc4 $70393\left(3^{\prime}-5^{\prime}\right)$ \\
\hline
\end{tabular}

Numbers are derived from GenBank databases. Length of CGls and analyzed numbers of $\mathrm{CpGs}$ are shown in parentheses in the columns labeled "position of CGI" and "PCR amplified region," respectively. CGI, CpG island. 

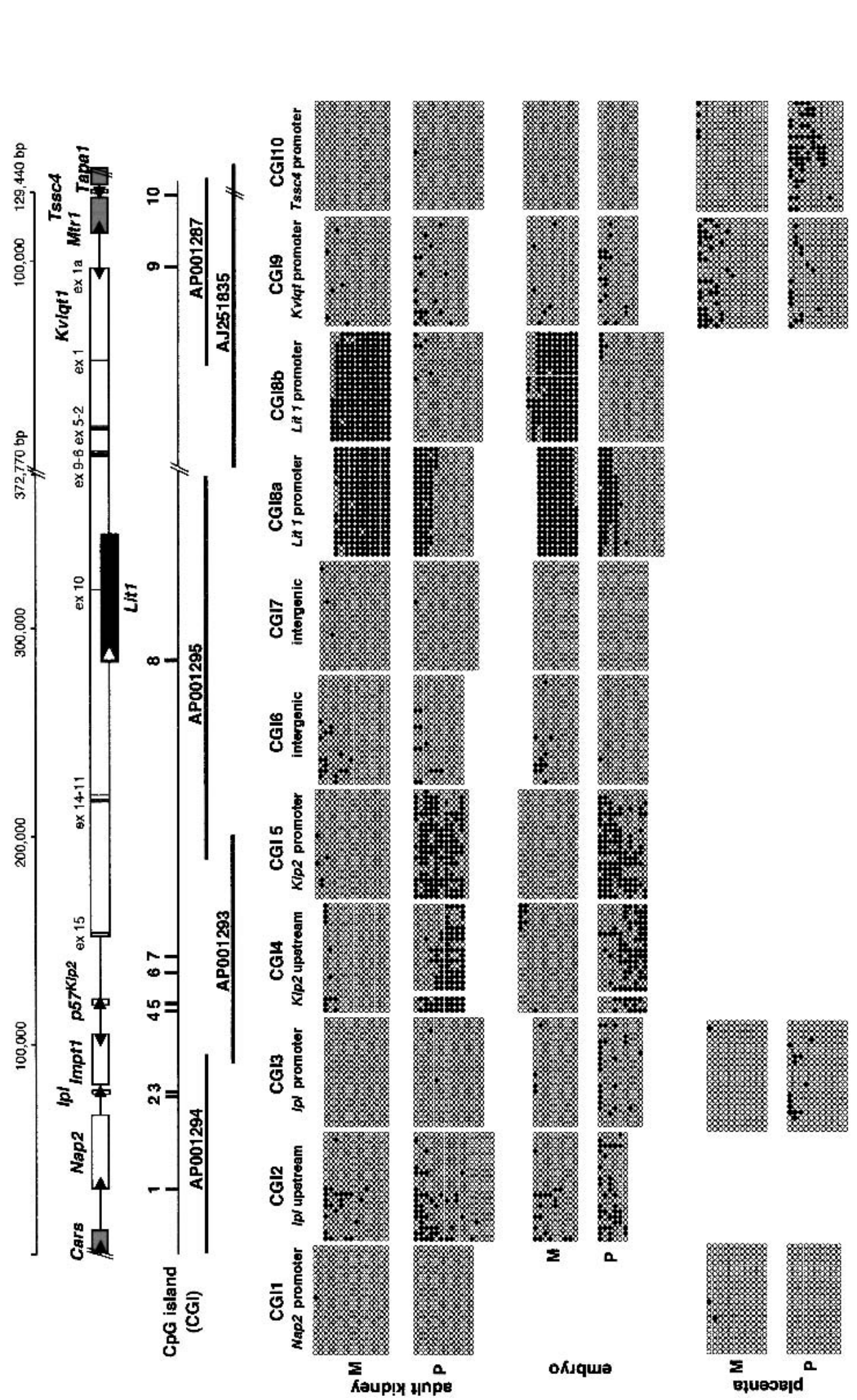

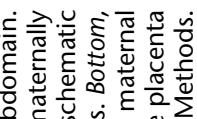

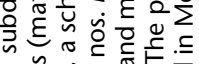

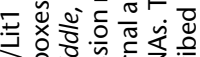

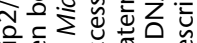

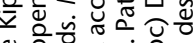

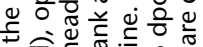

$\subseteq \bar{d}$

ชัญ

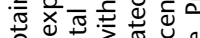

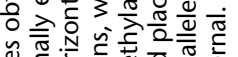

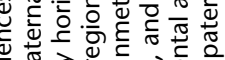

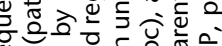

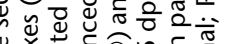

文

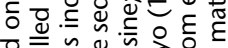

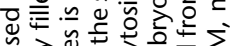

ฮे

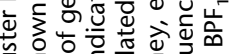

㱏兄 ᄃ

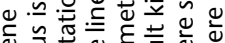

ठั

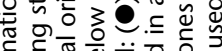

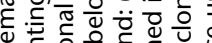

论航

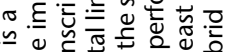

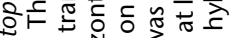

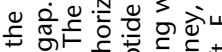

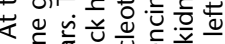

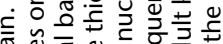

蛋

응 근

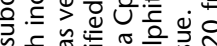

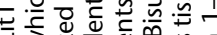

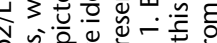

은 㟧웡 훙응.

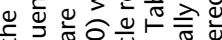

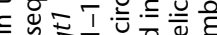

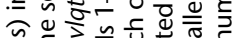

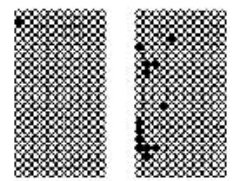

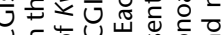

- 0 음

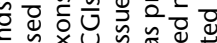

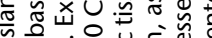

U.

U䒕氙可

हो 을 $\cong \xi$

등

哥

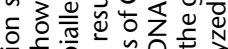

.은 는

돌.

屯

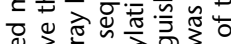

б。

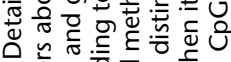

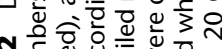

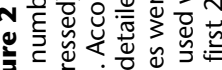

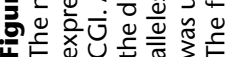




\section{CGIs 4, 5, 8, and 10 Associated with $p 57^{\text {Kip2 }}$, Lit1, and Tssc4 Carry the DMR in Somatic Tissues}

To define the methylation status of all CGIs, we performed sodium bisulphite sequencing using $\mathrm{BPF}_{1}$ genomic DNA (Fig. 2). The first $20 \mathrm{CpGs}$ of analyzed CGIs are presented. An adult

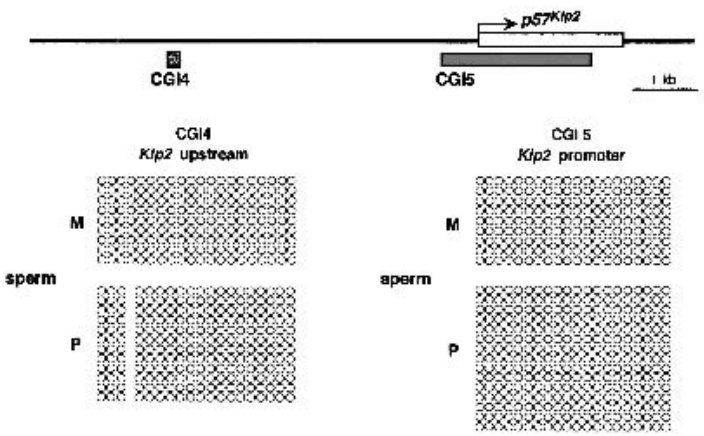

kidney and whole embryo derived from 10.5 days postconception (dpc) were used as somatic tissues, because it is known that most genes in this region were expressed and imprinted in these tissues. The placenta was used when it was proven that the gene was expressed monoallelically in this tissue.

First, we analyzed CGIs $1,3,5,8,9$, and 10 , which exist in the promoter of genes. Among these CGIs, differential methylation was dominantly observed in CGIs 5 and 8. Paternal methylation was observed in CGI5, that is, $p 57^{\text {Kip } 2}$ promoter, in adult kidney and embryo (Fig. 2). Most prominent methylation was observed in CGI8, located in the promoter region of Lit1. This CGI8 was separated into CGIs $8 \mathrm{a}$ and $8 \mathrm{~b}$ (Fig. 2, Fig. 3C). Their regions were heavily methylated on the maternal allele in kidney and embryo. However, CGI8a was also methylated partly on the paternal allele. Methylation of CGI10 was observed partially but preferentially on the paternal allele in placenta, in which Tssc 4 was expressed maternally. CGIs 1,3 , and 9 were not differentially methylated. CGI1 was not methylated in the tissues analyzed. Both alleles of CGIs 3 and 9 were partially but equivalently methylated in kidney, embryo, and placenta.

Second, CGIs 2 and 4, which lay upstream of genes, were analyzed. CGI2 was located upstream of $I p l$ and partially methylated in both alleles, but did not show any distinct bias of methylation. CGI4, located $4.1 \mathrm{~kb}$ upstream of $p 57^{K i p 2}$, showed paternal methylation as well as CGI5, as mentioned above. This pattern of methylation was maintained in embryo as well.

Finally, intergenic CGIs 6 and 7 located between $p 57^{\text {Kip } 2}$ and Kvlqt1 were analyzed. Their parental alleles were hypomethylated in kidney and embryo. The results were confirmed by analysis of the methylation status of some of these CGIs in the opposite cross, $\mathrm{PBF}_{1}$ mice.

As a result, DMRs were found in CGIs 4, 5, 8, and 10. Although CGIs 1, 3, and 9 existed near the promoter of the genes-Nap2, Ipl, and Kvlqt1, respectively, which have been reported as imprinted genes-these CGIs did not show any differential methylation in expressed tissues, but were hypomethylated in both alleles. Therefore, these CGIs located in $p 57^{\text {Kip } 2}$
Figure 3 Methylation status in gametes. (A) Nonparental methylation of CGls 4 and 5 in sperm. (Top) Schematic structure of CGls 4 and 5 in and around $p 57^{\text {Kipz }}$. The bent arrow indicates a transcriptional start site; the open box on the line represents $p 57^{\text {Kip } 2}$. The gray boxes below the line represent CGls 4 and 5 . The methylation status of sperm genomic DNA is presented. (B) Nonparental methylation of CGl10 in sperm. The methylation status of sperm genomic DNA is presented in TssC4 promoter. (C) Gametic methylation of CGl8 in oocyte but not in sperm. The methylation status of CGls $8 \mathrm{a}$ and $8 \mathrm{~b}$ is shown in sperm and oocyte. In oocyte, clones are grouped by separate PCRs. The schematic presentation is the same as shown in Fig. 2. However, the first 11 and first $16 \mathrm{CpG}$ are presented in CGI8a and CGI8b, respectively. These were analyzed by bisulphite sequencing in $\mathrm{BPF}_{1}$.
Genome Research www.genome.org 
upstream, $p 57^{\text {Kip } 2}$ promoter, Lit1 promoter, and Tssc4 promoter, respectively, were chosen for further analysis.

\section{Only CGI8 Is Methylated in Gametic Tissue}

We focused on the methylation status of CGIs $4,5,8$, and 10 in gametes, which showed differential methylation in somatic tissues. To clarify whether CGIs 4, 5, and 10 are methylated in gametic tissue, we performed bisulphite sequencing using sperm DNA of $\mathrm{BPF}_{1}$ mice, because their paternal alleles were specifically methylated in somatic tissues. Parental alleles of CGIs 4, 5, and 10 were not methylated at all in sperm DNA (Fig. 3A,B). Therefore, we concluded that gametic methylation of these CGIs did not occur in sperm.

In contrast, CGI8, which was methylated maternally in somatic tissues, was analyzed in growing oocytes and in sperm (Fig. 3C). To analyze oocytes, several PCRs were carried out on bisulphite-treated DNA. Clones were prepared from each PCR and sequenced. Clones derived from separate PCRs were not combined, to show that the variability that may occur among PCRs from the sample is due to PCR bias (Warnecke et al. 1998). Although various patterns of methylation were obtained in CGI8a, depending on the experiment, full methylation was consistently obtained in CGI8b on both alleles. On the other hand, sperm was not methylated in this region at all. We confirmed that CGI8, particularly CGI8b,

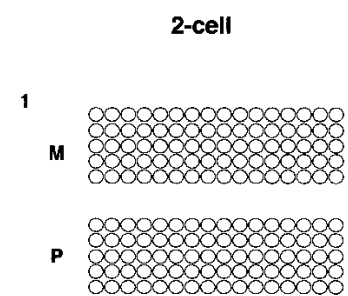

2

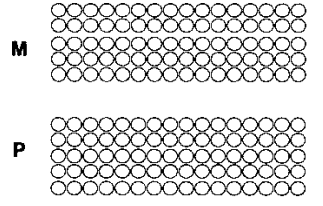

3

M

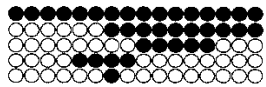

P

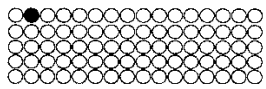

\section{(}

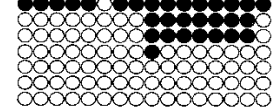

blastocyst
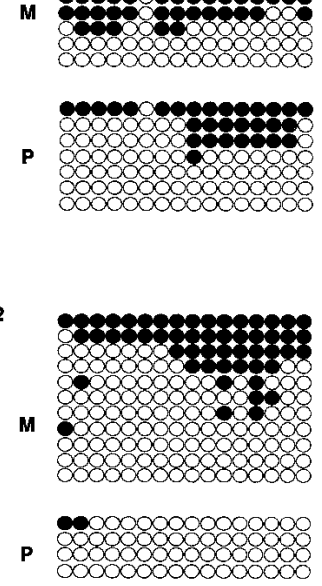

3

M

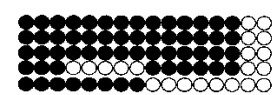

P

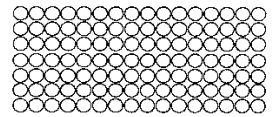

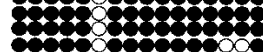
$\$ 0000000000000000$ 0000000000000000

Figure 4 Methylation status of CGI8b in preimplantation embryos. The methylation status of two-cell and blastocyst DNAs was analyzed in CGI8b. The presentation is basically the same as in Fig. $3 \mathrm{C}$. Clones are grouped by separate PCRs. Independent experiments were performed several times; representative results are shown. The primers are described in Methods. $F_{1}$ hybrid embryos used here are all $B P F_{1}$.

was fully methylated gametically, as reported previously (Engemann et al. 2000).

Overall analyses of 10 CGIs showed only one methylated region of CGI8 in gametes. As this region was a DMR and, in addition, had a gametic methylation, the CGI8 was designated as DMR-Lit1(DMR of Lit1) in the Kip2/Lit1 subdomain.

\section{Differential Methylation of CGI8b Is Gradually Established in Early Preimplantation Embryo}

The methylation status of CGI8 was analyzed in early preimplantation embryo (Fig. 4). We expected maternal methylation because this region was gametically methylated in oocyte. However, CGI8a was hypomethylated on the maternal allele at this stage, including two-cell, morula, and blastocyst (data not shown). CGI8b again showed maternal hypomethylation in two-cell, but this CGI showed preferentially maternal methylation in blastocyst (Fig. 4). This maternal methylation, however, reappeared completely at 10.5 dpc embryo, as mentioned above (Fig. 2). Thus, maternal methylation was complete between 3.5 and $10.5 \mathrm{dpc}$.

\section{Parental Expression and Methylation of $p 57^{K i p 2}$ and Litl Are Strictly Maintained Throughout Development}

We analyzed the parental expression and methylation of $p 57^{\text {Kip } 2}$ and Lit1 during development in somatic tissues, because it is likely that $p 57^{\text {Kip } 2}$ is a target gene of DMR-Lit1 and Lit1 involves the DMR-Lit1. The search for methylation status showed the CGI5 ( $p 57^{\text {Kip2 } 2}$ promoter) to be the DMR in somatic cells (Fig. 2). To survey the expression and methylation status of $p 57^{\text {Kip } 2}$ during the developmental stage, we performed RT-PCR and a methylation-sensitive enzyme assay. Both maternal expression and paternal methylation were tightly maintained throughout the stages of development (Fig. 5A, left).

CGI8 (Lit1 promoter) is also a DMR. Lit1 was expressed paternally and methylated maternally in somatic tissues. This expression and methylation were opposite those of $p 57^{\text {Kip } 2}$. We analyzed the expression and methylation status of Lit1 in CGI8b during the developmental stages. Paternal expression and maternal methylation of Lit1 were similarly maintained at all stages as well (Fig. 5A, right). A summary of the above results is depicted in Figure 5B. Allelic expression of Lit1 was further examined in many adult tissues, such as brain, skeletal muscle, spleen, heart, lung, liver, kidney, testis, and placenta. Lit1 was paternally expressed, except in testis, in which the gene was expressed biallelically (data not shown).

\section{Allelic Chromatin Conformation Around CGls 4, 5, and 8}

Because CGI8 is the DMR and the region for gametic methylation in the Kip2/Lit1 subdomain, it could be an ICR, as has been proposed by a number of groups (Lee et al. 1999; Mitsuya et al. 1999; Smilinich et al. 1999; Engemann et al. 2000). In some ICRs, their parental origin-specific chromatin structures were studied and nuclease-sensitive sites were identified (Hark and Tilghman 1998; Schweizer et al. 1999). To investigate the chromatin conformation around CGI8, we examined DNaseI hypersensitive sites (HSSs). To distinguish between the alleles, we used $\mathrm{BPF}_{1}$ hybrid mice and its reciprocal cross, $\mathrm{PBF}_{1}$. Nuclei from $\mathrm{BPF}_{1}$ and $\mathrm{PBF}_{1}$ primary fibroblasts were incubated with different amounts of DNase I. After purification, the DNA was digested with $B c l$ and additionally with poly- 
A
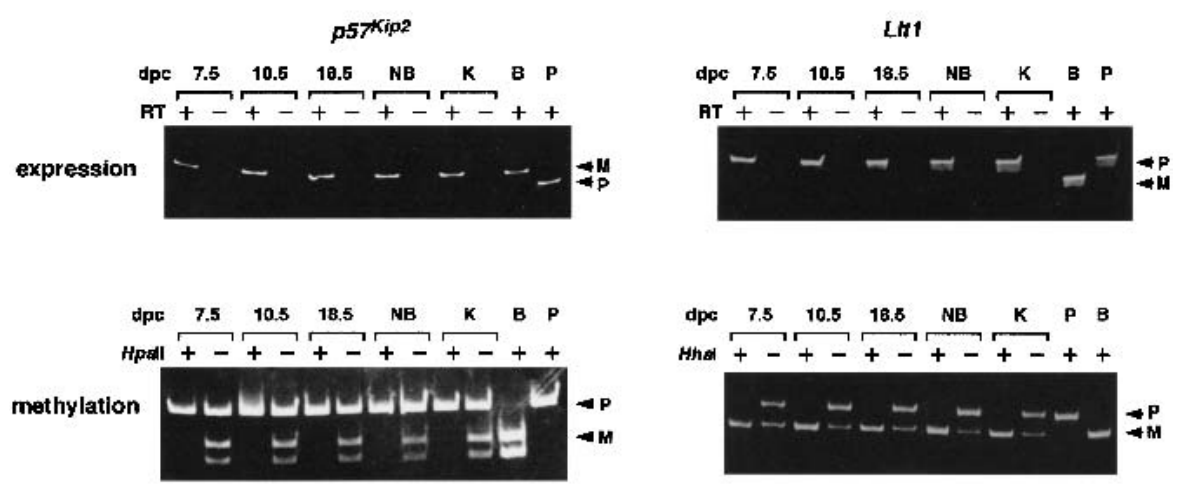

B

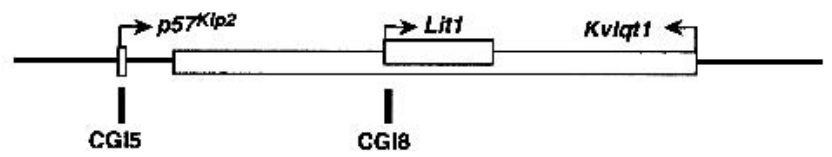

p57Kip2

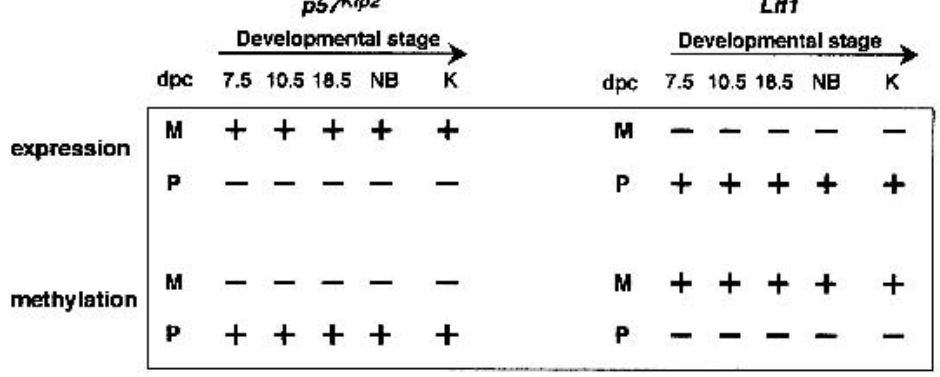

Figure 5 Parental expression and methylation of $p 57^{\text {Kip } 2}$ and Lit1 during development. (A) Allelic expression and methylation of $p 57^{k i p 2}$ and Lit1 in $\mathrm{F}_{1}$ mice. The mRNA and genomic DNA obtained from various tissues were used for RT-PCR and genomic PCR, respectively. Hpall and Hhal indicate restriction enzymes used for methylation-sensitive genomic PCR; +, digested; - , not digested. Tissues used for analyses were as follows: $7.5,10.5$, and $18.5 \mathrm{dpc}$ embryos; NB, whole newborn; K, adult kidney; $\mathrm{B}$, adult B6 kidney; P, adult PWK kidney. RT indicates reverse transcription; +, transcriptase added; - , no transcriptase. Primers are described in Methods. Two alleles were distinguished as described in Methods. $\mathrm{F}_{1}$ hybrid mice were all BPF ${ }_{1}$. (B) (Top) Schematic structure of $p 57^{\mathrm{Kip} 2}$, Lit1, and Kvlqt1. (Bottom) Schematic pattern of expression and methylation during development for $p 57^{K i p 2}$ and Lit1, respectively. In expression, +, expressed; -, nonexpressed. In methylation, +, methylated; -, nonmethylated.

morphic HindIII. The sites of cleavage were detected with a hybridization probe at the 5' end of a 6.3-kb HindIII/BclI fragment upstream of the LitI promoter. After digestion with BclI, a 3.2-kb fragment appeared. This length shifted to $2.3 \mathrm{~kb}$ by additional digestion with HindIII in $\mathrm{BPF}_{1}$ (Fig. 6A). This result indicated the presence of a hypersensitive site on the paternal chromosome at the 5 ' border of CGI8a, because a polymorphic HindIII site was found in a genomic DNA of PWK mouse, from which the paternal allele had been derived. These results were confirmed by use of the reciprocal cross, $\mathrm{PBF}_{1}$ (Fig. 6A). Digestion with HindIII did not give rise to any change in the pattern, because the polymorphic HindIII site was not found in the genomic DNA of B6 mouse, from which the paternal allele was derived. This hypersensitive site was named HSS- 1 .

It is thought that $p 57^{K i p 2}$ is one of the target genes in BWS (Reik and Maher 1997). Therefore, it is likely that this gene is under the control of DMRLit1. This gene has the DMR in CGIs 4 and 5. To understand the regulatory mechanism of this gene, we analyzed the chromatin structure in and around this gene. $\mathrm{F}_{1}$ genomic DNA was digested with DraI and subsequently by polymorphic $B s p \mathrm{H} 1$, whose recognition site is in the DraI fragment from the B6 genome but not from the PWK genome. After digestion with DraI, 5.2- and 2.3-kb fragments appeared along with a 7.4-kb fragment in $\mathrm{PBF}_{1}$. Both the 5.2- and 2.3-kb fragments remained in the same position after additional BspH1 digestion, but a 7.4-kb fragment gradually disappeared with an increment of DNase I, although $4.0 \mathrm{~kb}$ remained. These results indicated that hypersensitive sites (HSS-2 and HSS-3) were derived from maternal chromosome. The HSS- 2 existed just upstream of the transcription start site of this gene. The other HSS-3 was $3.0 \mathrm{~kb}$ further upstream of this gene. These data were confirmed by use of the probe, located between DraI and the HSS-3 site, and by use of the reciprocal cross, $\mathrm{BPF}_{1}$ (data not shown).

\section{DISCUSSION}

The methylation status of an imprinting Kip2/Lit1 subdomain spanning $500 \mathrm{~kb}$ on mouse chromosome 7F4/F5 was analyzed. All CGIs of the subdomain were analyzed by sodium bisulphite sequencing. Figure 7 summarizes the results of this study. On the maternal allele, DMR-Lit1 was methylated in oocyte, mid-embryo, and somatic tissues and Lit1 was not expressed, whereas flanking imprinted genes such as $p 57^{\text {Kip } 2}$ were unmethylated and expressed. In contrast, on the paternal allele, DMR-Lit1 was demethylated from sperm to somatic tissues throughout development and Lit1 was expressed, whereas flanking imprinted genes were repressed in expression but not methylated except for $p 57^{\text {Kip } 2}$ and Tssc4. Our results suggest that DMR-Lit1 is the ICR of this subdomain. The ICR is defined by the following characteristics: DMR, gametic methylation, and differential chromatin conformation (Ben-Porath and Cedar 2000). The disruption of this region would cause loss of imprinting. In fact, loss of imprinting of human LIT1 was observed in BWS as noted earlier (Lee et al. 1999; Mitsuya et al. 1999; Smilinich et al. 1999). This evidence, taken together with the presence of a paternally active chromatin structure near the DMR-Lit1, supports the idea that DMR-Lit1 is the ICR in the Kip2/Lit1 subdomain. The regulatory mechanism of this domain will be discussed in a later section. 
Yatsuki et al.

A

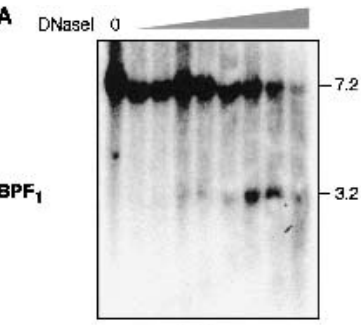

Bcn

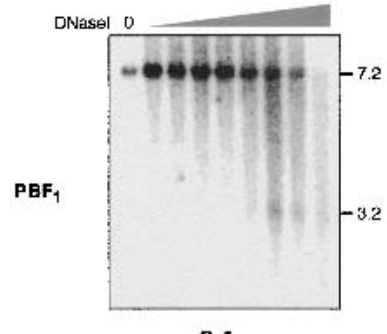

BcA

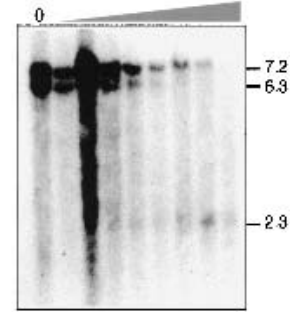

$B C A+H A d$

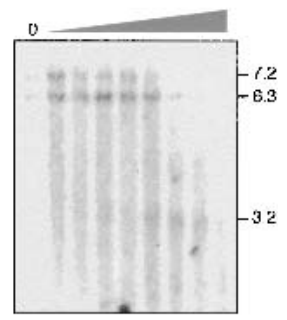

$B c A+H d$
B

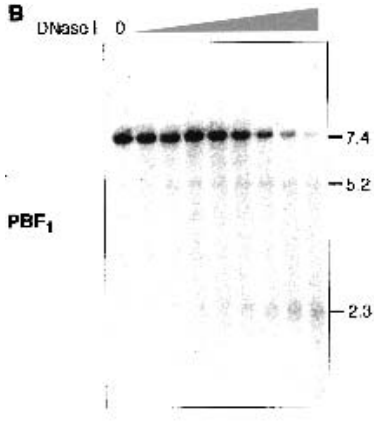

Dral

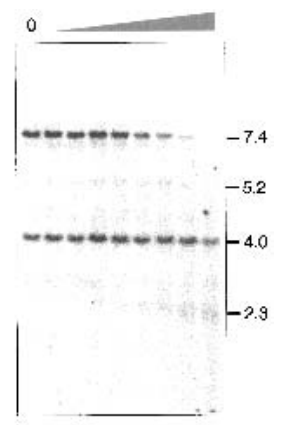

Dral + BepHI
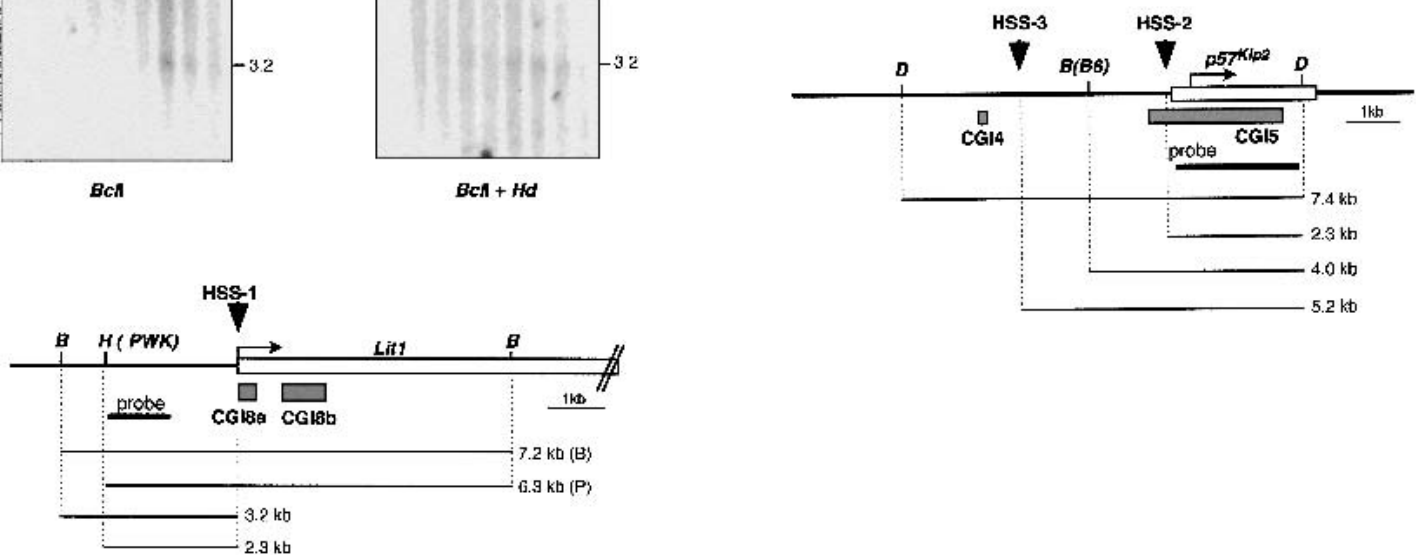

Figure 6 Parental-specific DNasel HSSs near and around CGIs 4, 5, and 8. (A) DNasel HSS on paternal allele near CGI8. Nuclei isolated from BPF 1 or $\mathrm{PBF}_{1}$ primary fibroblast in mice were treated with an increasing amount of DNase I. After extraction, the DNA was digested with $B c l$ or $B c / l$ and HindIII as indicated and subjected to Southern blotting analysis. The blots were probed with 1 kb of fragment amplified with the primer sets Lit- 3 and Lit-5. The diagram shown below depicts Lit 1 gene and CGI8 surrounded by restriction sites, with the start of transcription represented by the bent arrow; gray boxes below the gene represent CGI8a and 8b. Downward arrowhead indicates a nuclease HSS detected on the paternal chromosome, designated HSS-1. B, BCll; H, HindllI. Hindlll is the polymorphic recognition site in PWK but not in B6 mouse. (B) HSS on maternal allele around CGIs 4 and 5 . The same DNase l-treated DNA was used as above and treated similarly. Dral and $B s p H 1$ were used. BspH1 is the polymorphic restriction site in B6 mouse. The probe is a $p 57^{\text {Kip2 }} \mathrm{cDNA}$. The HSSs obtained were designated HSS-2 and HSS-3. D, Dral; B, BspH1.

How is this subdomain regulated? It would be useful to clarify the regulatory mechanism, particularly of $p 57^{\text {Kip } 2}$, in an imprinting cluster because this gene is directly responsible for BWS (Hatada et al. 1996; Lee et al. 1997; O'keefe et al. 1997). Chromosomal translocation within KvLQT1 has also caused this syndrome. It is thought that the primary cause of BWS in this case may be the loss of $p 57^{K I P 2}$ expression. It was experimentally proven that the regulation of imprinted genes was affected by targeted chromosomal translocation (Cleary et al. 2001). Using mice carrying a site-specific translocation separating $p 57^{K i p 2}$ and Kvlqt1, expression and imprinting of telomeric genes, including $p 57^{K i p 2}$, were greatly influenced. This result strongly indicated that the translocation physically separated the telomeric genes from enhancer elements; thus, the ICR would exist at a distance from these genes. At the very least these elements must be in the centromeric as opposed to the telomeric region. These results are compatible with our results because we suspected that the ICR in this subdomain would be the DMR-Lit1, that is, $160 \mathrm{~kb}$ apart from $p 57^{\text {Kip } 2}$ and located at the centromeric region.

On the other hand, the insulator model has been established in the imprinting of the Igf2/H19 subdomain (Thor- valdsen et al. 1998), and the same model was proposed in this Kip2/Lit1 subdomain (Horike et al. 2000; Cleary et al. 2001). Kanduri et al. (2002) showed that this DMR-Lit1 functions as an insulator. We also confirmed this result, but in our case, this DMR-Lit1 functioned bidirectionally (K. Joh and T. Mukai, unpubl.). This result is compatible with the proposed insular model, if we assume that the enhancer is in a more centromeric region than is the DMR-Lit1 (Fig. 7). Our present results suggest that methylated DMR-Lit1 would lose enhancer-blocking function on the maternal chromosome and therefore allow $p 57^{\text {Kip } 2}$ to contact the enhancers, whereas the demethylated DMR-Lit1 could function as an enhancerblocker on the paternal chromosome and hence disturb the interaction between enhancers and $p 57^{\text {Kip } 2}$. Furthermore, the finding that $p 57^{K i p 2}(C d k n 1 c)$ and I $p l$ again failed to express, when maternal methylation of the DMR-Lit1 was impaired by targeting of Dnmt3L (Bourchis et al. 2001), clearly indicates a close relationship between the DMR-Lit1 function and the expression of the clustered imprinted genes. However, the transgenic experiment conducted by John et al. (2001) gave more complicated results. The BAC transgene, which spans $315 \mathrm{~kb}$ and includes this DMR-Lit1 and $p 57^{\text {Kip } 2}$, showed en- 


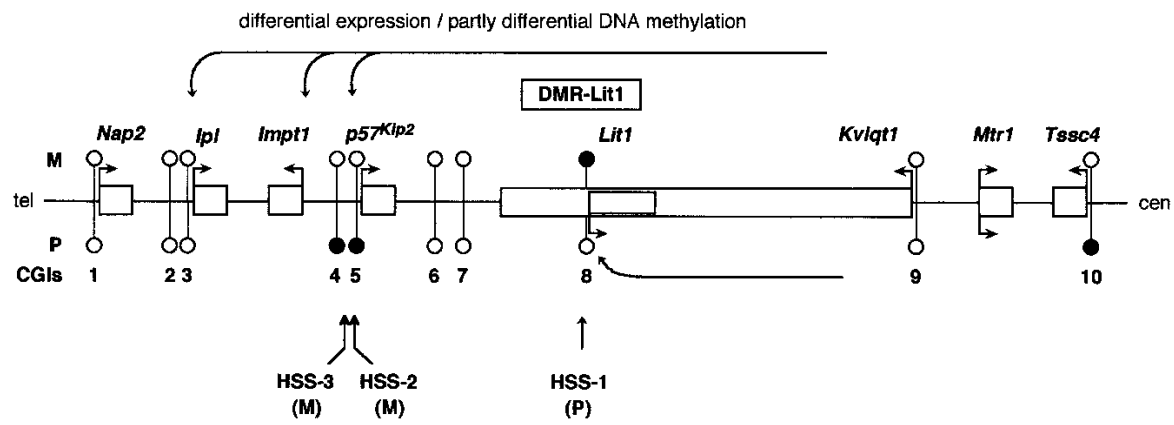

Figure 7 Imprinting regulation of Kip2/Lit1 subdomain by DMR-Lit1. Expression and DNA methylation status of imprinting cluster in this domain are depicted. The hypothetical mechanism of DMRLit-1 is described in the Discussion. Bent arrows indicate a parental-dependent transcription. Horizontal arrows pointing toward left show hypothetical enhancers that were suggested to exist experimentally (Cleary et al. 2001; John et al. 2001). Lollipops represent CGls 1 to 10. Closed lollipops: methylated DNA; open lollipops: nonmethylated DNA. M, maternal allele; P, paternal allele. HSS-1, HSS-2, and HSS-3 show nuclease-hypersensitive sites near CGI8, CGI4, and CGI5, respectively. Not drawn to scale.

hanced expression of $p 57^{\text {Kip } 2}$, but failed to show an imprinted expression of this gene. This result suggests that the existence of DMR-Lit1 is not sufficient for the imprinted expression of $p 57^{K i p 2}$, that additional imprinting elements are required for regulation of this subdomain, and that these elements must be extremely distant from $p 57^{\text {Kip } 2}$.

In general, it is thought that an imprinted gene has the DMR in its control region or at some other location which allows it to be expressed differentially (Ben-Porath and Cedar 2000). We analyzed all CGIs by bisulphite sequencing to search for the DMR in the mouse 7F4/F5 subdomain. To our knowledge, there have been no other attempts to examine the methylation status of one domain over $500 \mathrm{~kb}$ by bisulphite sequencing. We identified seven imprinted genes out of eight in the Kip2/Lit1 subdomain (Figs. 1,7). Six of seven imprinted genes had CGIs in their promoters, except for Impt1 (Table 1, Fig. 7). Three genes- $p 57^{\text {Kip } 2}$, Lit1, and Tssc4-out of six CGIassociated genes had the DMR. However, the other three genes-Nap2, Ipl, and Kvlqt1—had mostly no methylation in their own CGIs, even though these three genes were examined at the time when they showed a monoallelic expression in placenta. It was reported that these genes showed imprinted expression in placenta at 12.5-16.5 dpc depending on the gene analyzed (Qian et al. 1997; Caspary et al. 1998; En gemann et al. 2000), and we analyzed the placenta at $8.5 \mathrm{dpc}$ (Fig. 2) and $13.5 \mathrm{dpc}$ (data not shown); the same results were obtained. These results indicate that imprinted genes are not always associated with the DMR. This implies that there may be a critical CpG other than the CGIs or some other mechanism such as acetylation/deacetylation and methylation in histone protein. Alternatively, it is possible that the DMR is not required in each gene if the DMR-Lit1 controls this domain en bloc.

CGI8 was solely methylated in germ cells. CGI8b was fully methylated in growing oocyte on both alleles, but CGI8a was partially methylated. We believe that the primary imprint exists in CGI8b and that this methylation reaches CGI8a later on, after fertilization, because CGI8a finally acquires the full methylation in mid-embryo, as shown in Figure 2.

When we analyzed CpG methylation in CGI8b by bisulphite sequencing in early embryo, maternal hypomethylation was observed in two-cell, but preferentially maternal methylation reappeared in blastocyst. It is thought that once methylation is acquired in germ cells, it is usually resistant to genome-wide demethylation during the preimplantation em- bryo in the ICR, as indicated by H19 in mice (Warnecke et al. 1998). In our case, CGI8b was demethylated in two-cell. There are two possible explanations: CGI8b is hypomethylated everywhere, or the methylated region moved elsewhere. With regard to the first possibility, mouse Ndn was demonstrated to be demethylated at the promoter region in blastocyst, although the allelic methylation was maintained through the germ cell, two-cell, four-cell, and morula stages (Hanel and Wevrick 2001). With regard to the second possibility, sites 3 and 4 of region 2 in mouse $I g f 2 r$ were methylated in two-cell. However, site 3 was demethylated, whereas site 4 was maintained the methylated state in four-cell, implying that the methylated site moved from site 3 to site 4 at this stage (Shemer et al. 1996). Together these results indicate that differential methylation is not yet established during preimplantation embryo, as was the case with our results.

Engemann et al. (2000) analyzed Lit1-related CGI corresponding to CGI8b in early embryo by bisulphite analysis. Their results showed differential methylation in zygote. We analyzed two-cell and blastocyst, but not zygote. Our results showed hypomethylation in two-cell but differential methylation in blastocyst. When all of the results are combined, it turns out that CGI8b is methylated in oocyte, and after fertilization, maternal methylation is maintained in the zygote but disappears in two-cell and gradually reappears in blastocyst. We do not know at present why the pattern of methylation drastically changes during this short period. The region we analyzed was close to the $3^{\prime}$ end of CGI8b, but that examined by Engemann et al. is probably located at the $5^{\prime}$ end of CGI8b.

\section{METHODS}

\section{Collection of Tissues and Isolation of DNA and RNA}

Mice gametes, early embryos, and adult tissues were collected. Six-week-old females were superovulated by human chorionic gonadotropin (HCG) and mated. Oocytes, two-cell, morula, and blastocysts were collected from the oviducts or uterus by flushing. Oocytes were collected $12 \mathrm{~h}$ post-HCG and treated with hyaluronidase in $1 \times$ PBS to remove any remaining cumulus cells, then washed in acidic Tyrodes solution to dissolve the zona pellucida. Oocytes were then repeatedly washed in $1 \times$ PBS. Consequently, the contamination of other diploid cells was nearly zero in oocyte under microscopic observation. Two-cell, morula, and blastocysts were collected around $1.5,2.5$, and 3.5 dpc.

To prepare oocyte DNA, 40-45 pooled oocytes were resuspended in $160 \mu \mathrm{L}$ of $10 \mathrm{mM}$ Tris- $\mathrm{HCl}(\mathrm{pH} 8.0), 10 \mathrm{mM}$ EDTA, $150 \mathrm{mM} \mathrm{NaCl}, 0.1 \% \mathrm{SDS}, 2 \mu \mathrm{g}$ of $\lambda \mathrm{DNA}$, and $40 \mu \mathrm{g}$ of proteinase $\mathrm{K}$ and incubated for $3 \mathrm{~h}$ at $55^{\circ} \mathrm{C}$, then extracted with phenol-chloroform and precipitated with ethanol. Twocell, morula, and blastocyst DNAs were prepared with the same procedure from 25,15 , and three embryos, respectively. Sperm DNA was isolated by the two-digestion method as described (Yoshida et al. 1995). Kidney, embryo, and placenta DNAs were isolated using the QIAamp DNA mini Kit (QIAGEN). RNA from mouse tissues was extracted using 
ISOGEN (NIPPON GENE) according to the manufacturer's instructions.

\section{Computational Sequence Data Analysis}

DNA sequence data were derived from AP001293, AP001294, AP001295, AP001287, and AJ251835 (Paulsen et al. 2000; Yatsuki et al. 2000). To identify CGI, GRAIL and CpG percent analyses were performed (http://compbio.ornl.gov/Grail-1.3/, http://www.nih.go.jp/yoken/genebank/cpg_per.html).

\section{Genotyping and Allele Usage}

DNA polymorphisms were used to discriminate one allele from another. For this purpose, a laboratory mouse C57BL/6 (B) and a wild mouse PWK (P) were mated, and DNA or RNA from $\mathrm{F}_{1}$ mouse $\left([\mathrm{C} 57 \mathrm{BL} / 6 \times \mathrm{PWK}] \mathrm{F}_{1}\right)\left(\mathrm{BPF}_{1}\right)$ was used for the experiment. The opposite cross $\left([\mathrm{PWK} \times \mathrm{C} 57 \mathrm{BL} / 6] \mathrm{F}_{1}\right)\left(\mathrm{PBF}_{1}\right)$ was also employed to confirm the experiment.

\section{Sodium Bisulphite Treatment and Sequencing}

Sodium bisulphite treatment was carried out as described (Paulin et al. 1998), with some modifications. Two micrograms of DNA samples were denatured in $0.3 \mathrm{M} \mathrm{NaOH}$ at $37^{\circ} \mathrm{C}$ for $30 \mathrm{~min}$. To all samples, $208 \mu \mathrm{L}$ of $6.2 \mathrm{M}$ urea/bisulphite (pH 5) and $12 \mu \mathrm{L}$ of $10 \mathrm{mM}$ hydroquinone were added. The samples were incubated at $55^{\circ} \mathrm{C}$ for $16 \mathrm{~h}$. The treated DNA was purified using GENECLEAN (Bio 101) and eluted with $100 \mu \mathrm{L}$ of $\mathrm{H}_{2} \mathrm{O}$. For DNA desulfonation, $11 \mu \mathrm{L}$ of $3 \mathrm{M} \mathrm{NaOH}$ was added, and samples were incubated at $37^{\circ} \mathrm{C}$ for $15 \mathrm{~min}$. Two micrograms of glycogen were added to the DNA solution, precipitated with $166 \mu \mathrm{L}$ of $5 \mathrm{M}$ ammonium acetate and three volumes of ethanol, and resuspended in $30 \mu \mathrm{L}$ of $\mathrm{H}_{2} \mathrm{O}$. Oocyte, two-cell, morula, and blastocyst DNAs were finally resuspended in $10 \mu \mathrm{L}$ of $\mathrm{H}_{2} \mathrm{O}$.

PCRs were carried out using bisulphite-treated DNA and each primer set. The following primer pairs were used for amplification, with annealing temperatures shown in parentheses. Materials used for this analysis were somatic tissues such as adult kidney, embryo, placenta, and sperm, except for oocyte and early embryo. For CGI1, CN-BS1/CN-BS2 followed by CN-BS2/CN-BS5 $\left(58.5^{\circ} \mathrm{C}\right)$; for CGI2, NI-BS2/NI-BS3 followed by NI-BS1/NI-BS2 $\left(58^{\circ} \mathrm{C}\right)$; for CGI3, IP-BS1/IP-BS2 followed by IP-BS1/IP-BS3 $\left(58^{\circ} \mathrm{C}\right)$; for CGI4, BS-1F/BS-1R $\left(57^{\circ} \mathrm{C}\right)$; for CGI5, $\mathrm{KP}-\mathrm{BS} 1 / \mathrm{KP}-\mathrm{BS} 2$ followed by KP-BS1/KP-BS3 $\left(57^{\circ} \mathrm{C}\right)$; for CGI6, CG6-BS2/CG6-BS3 $\left(57.5^{\circ} \mathrm{C}\right)$; for CGI7, CG7-BS3/CG7-BS5 followed by CG7-BS2/CG7-BS4 $\left(57^{\circ} \mathrm{C}\right)$; for CGI8a, Lit-BS9/LitBS10 followed by Lit-BS12/Lit-BS9 $\left(57.5^{\circ} \mathrm{C}\right)$; for CGI8b, Lit$\mathrm{BS} 1 /$ Lit-BS2 followed by Lit-BS4/Lit-BS2 $\left(58^{\circ} \mathrm{C}\right)$; for CGI9, Kv$\mathrm{BS} 1 / \mathrm{Kv}$-BS5 followed by $\mathrm{Kv}-\mathrm{BS} 1 / \mathrm{Kv}-\mathrm{BS} 2\left(58.5^{\circ} \mathrm{C}\right)$; for CGI10, ST-BS1/ST-BS2 followed by ST-BS1/ST-BS3 $\left(58.5^{\circ} \mathrm{C}\right)$. In particular, analyses of CGI8a and $8 \mathrm{~b}$ in oocytes and early embryos were carried out as follows. For CGI8a, Lit-BS10/Lit$\mathrm{BS} 16$ was followed by Lit-BS12/Lit-BS16 $\left(56^{\circ} \mathrm{C}\right)$; for CGI8b, Lit-BS2/Lit-BS4 was followed by Lit-BS4/Lit-BS21 $\left(57^{\circ} \mathrm{C}\right)$. Primer sequences are as follows.

CN-BS1 5'-GTAGATAGAGGGTTAGAAGG-3', CN-BS2 5'-CCAACAAAACCACCTACCAT-3', CN-BS5 5'-AGAAGGTTTTGAGAAGTAGG-3', NI-BS1 5'-TGGGAATTTTGGAGGAGTTG-3', NI-BS2 5'-ACCCTACAATACTCAACCAC-3', NI-BS3 5'-TAGTAGGGGATTTTTGGGGT-3', IP-BS1 5'-ATGGGTAAGGGGTAGTTTGG-3', IP-BS2 5'-ACATTCCAAATCCCCTCTCC-3', IP-BS3 5'-CATTCACTTTCCCCATACCC-3', BS-1F 5'-GTGGTCTTGGACTTCTAGAACACT-3', BS-1R 5'-CTATTCTTAAAACCACTACCAAA-3', KP-BS1 5'-AGGATTTAGTTGGTAGTAGT-3', KP-BS2 5'-TATCCTATCCAACTTAAACC-3', KP-BS3 5'-TTTTCAATTTCAACAACACC-3', CG6-BS2 5'-ACAACCCCATTATAAAACCC-3',
CG6-BS3 5'-TGATTTTGGTGGGTTAGAAG-3', CG7-BS2 5'-CCTAACCTATACTAAAAACC-3', CG7-BS3 5'-AGTTTGTTTGGAGAAGAAAG-3', CG7-BS4 5'-GTTGGGGGGTGGGGTAGTTT-3', CG7-BS5 5'-ATCCCAAACCAACCCCTATA-3', Lit-BS1 5'-GTGTGATTTTATTTGGAGAG-3', Lit-BS2 5'-AATCCCCCACACCTAAATTC-3', Lit-BS4 5'-TAAGGTGAGTGGTTTAGGAT-3', Lit-BS9 5'-CTAACTAATATAACCTCACC-3', Lit-BS10 5'-GGTTTAGTTAGGAAGGGATG-3', Lit-BS12 5'-GGATGAGGAAGGTAGGTTTT-3', Lit-BS16 5'-AACCAAAATACACCATCATA-3', Lit-BS21 5'-CCACTATAAACCCACACATA-3', Kv-BS1 5'-GGTTGGTGTATTGTAAGTGT-3', Kv-BS2 5'-CCCTTCTCACTAAAACTAAC-3', Kv-BS5 5'-ACTAACAACAATAACTACCC-3', ST-BS1 5'-TTAGGGAGGTTAGTGTTTAT-3', ST-BS2 5'-AAACACAAAACCCACACCAC-3', ST-BS3 5'-AACTACAAACCTCAACCCTT-3'.

The standard reaction mixture included $1 \mu \mathrm{L}$ of bisulphite-treated DNA, $2.0 \mathrm{mM} \mathrm{MgCl}_{2}, 0.2 \mathrm{mM}$ dNTPs, $0.5 \mu \mathrm{M}$ primers, and 1 unit of LA Taq polymerase (Takara Shuzo) in 10 $\mu \mathrm{L}$. The amplification protocol was as follows: denaturation at $96^{\circ} \mathrm{C}$ for $2 \mathrm{~min}$, followed by 45 cycles at $96^{\circ} \mathrm{C}$ for $30 \mathrm{sec}$, each annealing temperature for $30 \mathrm{sec}, 72^{\circ} \mathrm{C}$ for $45 \mathrm{sec}$, and final elongation at $72^{\circ} \mathrm{C}$ for $3 \mathrm{~min}$ with a UNOII thermocycler (Whatman Biometra). The second PCR was performed in 30 cycles. To confirm the bisulphite reaction, the DMR upstream of $H 19$ was used as a control. The methylated and unmethylated CpGs were almost equivalent in kidney, and full methylation was observed in sperm, as has been described (Warnecke et al. 1998).

PCR products were cloned into pT-7-blue vector, and each cloned PCR product was amplified by colony-PCR using a Takara Ex Taq kit (Takara Shuzo) and the following primers: primer1 5'-TCCGGCTCGTATGTTGTGTGGA-3', primer2 5'GTGCTGCAAGGCGATTAAGTTGG-3'. The amplified products were treated with exonuclease I and shrimp alkaline phosphatase (Amersham Pharmacia Biotech) and subjected to sequencing reaction using BigDye (Applied Biosystems) and DYEnamicTM ET terminator kits (Amersham Pharmacia Biotech).

\section{RT-PCR and Methylation-Sensitive Enzyme Assay}

RNA PCR kit (Takara Shuzo) was used for reverse transcriptasebased cDNA preparation. The following primers were used for the RT-PCR assay: for $p 57^{K i p 2}$, KipBF/KipBR $\left(60^{\circ} \mathrm{C}\right)$; for Lit1, LchipF/LchipR $\left(64^{\circ} \mathrm{C}\right) . \mathrm{BPF}_{1}$ DNA was digested with either $H p a I I$ or HhaI and then subjected to the methylation-sensitive PCR assay. The following primers were used: for $p 57^{K i p 2}$, Kip2aF/Kip2aR $\left(64^{\circ} \mathrm{C}\right)$; for Lit1, LchipF/LchipR $\left(64^{\circ} \mathrm{C}\right)$.

KipBF 5'-CCGGGTGATGAGCTGGGAAC-3', KipBR 5'-AGAGAGGCTGGTCCTTCAGC-3', LchipF 5'-GCCGAGTCAGAACGCACTGG-3', LchipR 5'-TTCCCAATCCCCCACACCTG-3', Kip2aF 5'-GCGTCGCGGTGTCACGTTAC-3', Kip2aR 5'-TCGGAGCTTGCCTGCCTGTT-3'.

PCRs were performed using an LA Taq PCR system (Takara Shuzo). To distinguish between two alleles of $p 57^{\text {Kip2 }}$, 24 bp of deletion and Eco109I RFLP between B6 and PWK were used for the expression assay and the methylation assay, respectively. NciI RFLP was used for Lit1.

\section{Mapping DNase I-Hypersensitive Sites}

Preparation of nuclei, DNase I treatment, and purification of the DNA were carried out exactly as described (Sambrook and Russell 2001). Approximately $10^{8}$ fibroblast cells were used to collect nuclei from the cell (Hu et al. 1997). The primary fi- 
broblast was established from newborn mice of $\mathrm{PBF}_{1}$ or $\mathrm{BPF}_{1}$. We confirmed that at the least, the expression and methylation of Lit1 and $p 57^{\text {Kip } 2}$ were maintained the same as those of endogenous genes in this system. The DNase I used was RQ1 RNase-free DNase (Promega). The primers used for probe preparation of Southern blotting analyses in CGI8 were the following.

Lit-3 5'-CAGACCTTTGGGAAACCCAC-3'

Lit-5 5'-CTCAGAAGCTACTCCTAGCT-3'.

The probe for the Southern analysis in CGIs 4 and 5 was $p 57^{K i p 2}$ cDNA.

\section{ACKNOWLEDGMENTS}

We thank all of the members of the Department of Biochemistry at Saga Medical School. This work was supported by grants-in-aid for Scientific Research on Priority Areas and for JSPS Fellows from the Ministry of Education, Culture, Sports, Science and Technology of Japan, and from the Uehara Memorial Foundation.

The publication costs of this article were defrayed in part by payment of page charges. This article must therefore be hereby marked "advertisement" in accordance with 18 USC section 1734 solely to indicate this fact.

\section{REFERENCES}

Avner, P. and Heard, E. 2001. X-chromosome inactivation: Counting, choice and initiation. Nat. Rev. Genet. 2: 59-67.

Baylin, S.B., Esteller, M., Rountree, M.R., Bachman, K.E., Schuebel, K., and Herman, J.G. 2001. Aberrant patterns of DNA methylation, chromatin formation and gene expression in cancer. Hum. Mol. Genet. 10: 687-692.

Ben-Porath, I. and Cedar, H. 2000. Imprinting: Focusing on the center. Curr. Opin. Genet. Dev. 10: 550-554.

Bourchis, D., Xu, G.L., Lin, C.S., Bollman, B., and Bestor, T.H. 2001. Dnmt $3 \mathrm{~L}$ and the establishment of maternal genomic imprints. Science 294: 2536-2539.

Caspary, T., Cleary, M.A., Baker, C.C., Guan, X.J., and Tilghman, S.M. 1998. Multiple mechanisms regulate imprinting of the mouse distal chromosome 7 gene cluster. Mol. Cell. Biol. 18: 3466-3474.

Cleary, M.A., van Raamsdonk, C.D., Levorse, J., Zheng, B., Bradley, A,. and Tilghman, S.M. 2001. Disruption of an imprinted gene cluster by a targeted chromosomal translocation in mice. Nat. Genet. 29: 78-82.

Dao, D., Frank, D., Qian, N., O'Keefe, D., Vosatka, R.J., Walsh, C.P., and Tycko, B. 1998. IMPT1, an imprinted gene similar to polyspecific transporter and multi-drug resistance genes. Hum. Mol. Genet. 7: 597-608.

Engemann, S., Strodicke, M., Paulsen, M., Franck, O., Reinhardt, R., Lane, N., Reik, W., and Walter, J. 2000. Sequence and functional comparison in the Beckwith-Wiedemann region: Implications for a novel imprinting centre and extended imprinting. Hum. Mol. Genet. 9: 2691-2706.

Feinberg, A.P. 2000. The two-domain hypothesis in Beckwith-Wiedemann syndrome. J. Clin. Invest. 106: 739-740.

Ferguson-Smith, A.C. and Surani, M.A. 2001. Imprinting and the epigenetic asymmetry between parental genomes. Science 293: 1086-1089.

Gould, T.D. and Pfeifer, K. 1998. Imprinting of mouse Kvlqt1 is developmentally regulated. Hum. Mol. Genet. 7: 483-487.

Hanel, M.L. and Wevrick, R. 2001. Establishment and maintenance of DNA methylation patterns in mouse Ndn: Implications for maintenance of imprinting in target genes of the imprinting center. Mol. Cell Biol. 21: 2384-2392.

Hark, A.T. and Tilghman, S.M. 1998. Chromatin conformation of the $H 19$ epigenetic mark. Hum. Mol. Genet. 7: 1979-1985.

Hatada, I. and Mukai, T. 1995. Genomic imprinting of $p 57^{K I P 2}$, a cyclin-dependent kinase inhibitor, in mouse. Nat. Genet. 11: 204-206.

Hatada, I., Ohashi, H., Fukushima, Y., Kaneko, Y., Inoue, M. Komoto, Y., Okada, A., Ohishi, S., Nabetani, A., Morisaki, H., et al. 1996. An imprinted gene $p 57^{K I P 2}$ is mutated in Beckwith-Wiedemann syndrome. Nat. Genet. 14: 171-173.

Horike, S., Mitsuya, K., Meguro, M., Kotobuki, N., Kashiwagi, A.,
Notsu, T., Schulz, T.C., Shirayoshi, Y., and Oshimura, M. 2000. Targeted disruption of the human LIT1 locus defines a putative imprinting control element playing an essential role in Beckwith-Wiedemann syndrome. Hum. Mol. Genet. 9: 2075-2083.

$\mathrm{Hu}$, J.F., Vu, T.H., and Hoffman, A.R. 1997. Genomic deletion of an imprint maintenance element abolishes imprinting of both insulin-like growth factor II and H19. J. Biol. Chem. 272: 20715-20720.

John, R.M., Ainscough, J.F., Barton, S.C., and Surani, M.A. 2001. Distant cis-elements regulate imprinted expression of the mouse $p 57^{\text {Kip2 }}$ (Cdkn1c) gene: Implications for the human disorder, Beckwith-Wiedemann syndrome. Hum. Mol. Genet. 10: $1601-1609$.

Kanduri, C., Fitzpatrick, G., Mukhopadhyay, R., Kanduri, M., Lobanenkov, V., Higgins, M., and Ohlsson, R. 2002. A differentially methylated imprinting control region within the Kcnq1 locus harbors a methylation-sensitive chromatin insulator. J. Biol. Chem. 277: 18106-18110.

Lee, M.P., DeBaun, M., Randhawa, G., Reichard, B.A., Elledge, S.J., and Feinberg, A.P. 1997. Low frequency of $p 57^{K I P 2}$ mutation in Beckwith-Wiedemann syndrome. Am. J. Hum. Genet. 61: 304-309.

Lee, M.P., DeBaun, M.R., Mitsuya, K., Galonek, H.L., Brandenburg, S., Oshimura, M., and Feinberg, A.P. 1999. Loss of imprinting of a paternally expressed transcript, with antisense orientation to KVLQT1, occurs frequently in Beckwith-Wiedemann syndrome and is independent of insulin-like growth factor II imprinting. Proc. Natl. Acad. Sci. 96: 5203-5208.

Maher, E.R. and Reik, W. 2000. Beckwith-Wiedemann syndrome: Imprinting in clusters revisited. J. Clin. Invest. 105: 247-252.

Mitsuya, K., Meguro, M., Lee, M.P., Katoh, M., Schulz, T.C., Kugoh, H., Yoshida, M.A., Niikawa, N., Feinberg, A.P., and Oshimura, M. 1999. LIT1, an imprinted antisense RNA in the human KvLQT1 locus identified by screening for differentially expressed transcripts using monochromosomal hybrids. Hum. Mol. Genet. 8: $1209-1217$.

Morisaki, H., Hatada, I., Morisaki, T., and Mukai, T. 1998. A novel gene, ITM, located between $p 57^{K i p 2}$ and $I P L$, is imprinted in mice. DNA Res. 5: 235-240.

O'Keefe, D., Dao, D., Zhao, L., Sanderson, R., Warburton, D., Weiss, L., Anyane-Yeboa, K., and Tycko, B. 1997. Coding mutations in $p 57^{K I P 2}$ are present in some cases of Beckwith-Wiedemann syndrome but are rare or absent in Wilms tumors. Am. J. Hum. Genet. 61: 295-303.

Onyango, P., Miller, W., Lehoczky, J., Leung, C.T., Birren, B., Wheelan, S., Dewar, K., and Feinberg, A.P. 2000. Sequence and comparative analysis of the mouse 1-megabase region orthologous to the human 11p15 imprinted domain. Genome Res. 10: 1697-1710.

Paulin, R., Grigg, G.W., Davey, M.W., and Piper, A.A. 1998. Urea improves efficiency of bisulphite-mediated sequencing of $5 '$-methylcytosine in genomic DNA. Nucleic Acids Res. 26: 5009-5010.

Paulsen, M., Davies, K.R., Bowden, L.M., Villar, A.J., Franck, O., Fuermann, M., Dean, W.L., Moore, T.F., Rodrigues, N., Davies, K.E., et. al. 1998. Syntenic organization of the mouse distal chromosome 7 imprinting cluster and the Beckwith-Wiedemann syndrome region in chromosome 11p15.5. Hum. Mol. Genet. 7: 1149-1159.

Paulsen, M., El-Maarri, O., Engemann, S., Strodicke, M., Franck, O., Davies, K., Reinhardt, R., Reik, W., and Walter J. 2000. Sequence conservation and variability of imprinting in the Beckwith-Wiedemann syndrome gene cluster in human and mouse. Hum. Mol. Genet. 9: 1829-1841.

Qian, N., Frank, D., O'Keefe, D., Dao, D., Zhao, L., Yuan, L., Wang, Q., Keating, M., Walsh, C., and Tycko, B. 1997. The IPL gene on chromosome 11p15.5 is imprinted in humans and mice and is similar to TDAG51, implicated in Fas expression and apoptosis. Hum. Mol. Genet. 6: 2021-2029.

Razin, A. and Cedar, H. 1991. DNA methylation and gene expression. Microbiol. Rev. 55: 451-458.

Reik, W. and Maher, E.R. 1997. Imprinting in clusters: Lessons from Beckwith-Wiedemann syndrome. Trends Genet. 13: 330-334.

Reik, W. and Walter, J. 2001. Genomic imprinting: Parental influence on the genome. Nat. Rev. Genet. 2: 21-32.

Sambrook, J. and Russell, D.W. 2001. Molecular cloning: A laboratory manual, 3rd ed., chapter 17. Cold Spring Harbor Laboratory Press, Cold Spring Harbor, NY.

Schweizer, J., Zynger, D., and Francke, U. 1999. In vivo nuclease hypersensitivity studies reveal multiple sites of parental 
Yatsuki et al.

origin-dependent differential chromatin conformation in the 150 kb SNRPN transcription unit. Hum. Mol. Genet. 8: 555-566.

Shemer, R., Birger, Y., Dean, W.L., Reik, W., Riggs, A.D., and Razin, A. 1996. Dynamic methylation adjustment and counting as part of imprinting mechanisms. Proc. Natl. Acad. Sci. 93: 6371-6376.

Shemer, R., Birger, Y., Riggs, A.D., and Razin, A. 1997. Structure of the imprinted mouse Snrpn gene and establishment of its parental-specific methylation pattern. Proc. Natl. Acad. Sci. 94: 10267-10272.

Smilinich, N.J., Day, C.D., Fitzpatrick, G.V., Caldwell, G.M., Lossie, A.C., Cooper, P.R., Smallwood, A.C., Joyce, J.A., Schofield, P.N., Reik, W., et. al. 1999. A maternally methylated CpG island in KvLQT1 is associated with an antisense paternal transcript and loss of imprinting in Beckwith-Wiedemann syndrome. Proc. Natl. Acad. Sci. 96: 8064-8069.

Stöger, R., Kubicka, P., Liu, C.G., Kafri,T., Razin, A., Cedar, H., and Barlow, D.P. 1993. Maternal-specific methylation of the imprinted mouse Igf $2 r$ locus identifies the expressed locus as carrying the imprinting signal. Cell 73: 61-71.

Sun, F.L., Dean, W.L., Kelsey, G., Allen, N.D., and Reik, W. 1997. Transactivation of Igf2 in a mouse model of Beckwith-Wiedemann syndrome. Nature 389: 809-815.

Thorvaldsen, J.L., Duran, K.L., and Bartolomei, M.S. 1998. Deletion of the $\mathrm{H} 19$ differentially methylated domain results in loss of imprinted expression of $H 19$ and Igf2. Genes \& Dev. 12: 3693-3702.

Tilghman, S.M. 1999. The sins of the fathers and mothers: Genomic imprinting in mammalian development. Cell 96: 185-193.

Tremblay, K.D., Saam, J.R., Ingram, R.S., Tilghman, S.M., and Bartolomei, M.S. 1995. A paternal-specific methylation imprint marks the alleles of the mouse H19 gene. Nat. Genet. 9: 407-413.
Warnecke, P.M., Mann, J.R., Frommer, M., and Clark, S.J. 1998. Bisulphite sequencing in preimplantation embryos: DNA methylation profile of the upstream region of the mouse imprinted H19 gene. Genomics 51: 182-190.

Yatsuki, H., Watanabe, H., Hattori, M., Joh, K., Soejima, H., Komoda, H., Xin, Z., Zhu, X., Higashimoto, K., Nishimura, M., et al. 2000. Sequence-based structural features between Kvlqt1 and Tapa1 on mouse chromosome 7F4/F5 corresponding to the Beckwith-Wiedemann syndrome region on human 11p15.5: Long-stretches of unusually well conserved intronic sequences of kvlqt1 between mouse and human. DNA Res. 7: 195-206.

Yoshida, K., Sekiguchi, K., Mizuno, N., Kasai, K., Sakai, I., Sato, H., and Seta, S. 1995. The modified method of two-step differential extraction of sperm and vaginal epithelial cell DNA from vaginal fluid mixed with semen. Forensic Sci. Int. 72: 25-33.

Zhang, P., Liegeois, N.J., Wong, C., Finegold, M., Hou, H., Thompson, J.C., Silverman, A., Harper, J.W., DePinho, R.A., and Elledge, S.J. 1997. Altered cell differentiation and proliferation in mice lacking $p 57^{K i p 2}$ indicates a role in Beckwith-Wiedemann syndrome. Nature 387: 151-158.

\section{WEB SITE REFERENCES}

http://compbio.ornl.gov/Grail-1.3/; Gene Recognition and Assembly Internet Link (Version 1.3).

http://www.nih.go.jp/yoken/genebank/cpg_per.html; test program for $\mathrm{C}+\mathrm{G} \%+\mathrm{CpG}$ graph.

Received January 19, 2002; accepted in revised form September 10, 2002.

1870 Genome Research 
Genome Research 12: 1860-1870 (2002)

\section{Domain Regulation of Imprinting Cluster in Kip2/Lit1 Subdomain on Mouse Chromosome 7F4/F5: Large-Scale DNA Methylation Analysis Reveals That DMR-Lit1 Is a Putative Imprinting Control Region}

Hitomi Yatsuki, Keiichiro Joh, Ken Higashimoto, Hidenobu Soejima, Yuji Arai, Youdong Wang, Izuho Hatada, Yayoi Obata, Hiroko Morisaki, Zhongming Zhang, Tetsuji Nakagawachi, Yuji Satoh, and Tsunehiro Mukai

DNA hypomethylation of the maternal allele in preimplantation embryo was reported in Figure 4 of this paper. In part of this figure, it was reported that remarkable loss of methylation in the 2-cell stage was observed when the CpG island, CGI8b, was analyzed. However, efforts to reproduce this result with primers located near the initial sites have been unsuccessful. Therefore, the conclusion drawn from the figure-that differential methylation is not yet established during preimplantation embryo-is not supported by the authors' subsequent experiments. The authors sincerely apologize for any inconvenience this may have caused other investigators in the field. 


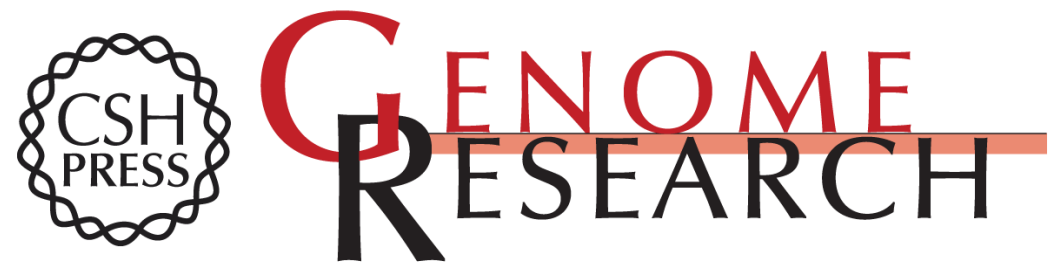

\title{
Domain Regulation of Imprinting Cluster in Kip2/Lit1 Subdomain on Mouse Chromosome 7F4/F5: Large-Scale DNA Methylation Analysis Reveals That DMR-Lit1 Is a Putative Imprinting Control Region
}

Hitomi Yatsuki, Keiichiro Joh, Ken Higashimoto, et al.

Genome Res. 2002 12: 1860-1870

Access the most recent version at doi:10.1101/gr.110702

\author{
Related Content Retraction \\ Genome Res. September , 2004 14: 1820 \\ References This article cites 46 articles, 13 of which can be accessed free at: \\ http://genome.cshlp.org/content/12/12/1860.full.html\#ref-list-1 \\ Articles cited in: \\ http://genome.cshlp.org/content/12/12/1860.full.html\#related-urls
}

\section{License}

Email Alerting Service
Receive free email alerts when new articles cite this article - sign up in the box at the top right corner of the article or click here.

\section{Affordable, Accurate Sequencing.}

